\title{
The vault
}

Ludwig Gutmann, MD

Neurology ${ }^{\circledR}$ 2018;91:94-96. doi:10.1212/WNL.0000000000005760

The marshal leaned against the rough timbered wall to steady himself, looking down at his naked torso. His dark gingham shirt and jeans lay neatly folded on the seat of an old chair, his boots and Stetson dropped next to it on the wooden floor. His pale, hairless scalp, chest, and arms were in sharp contrast to his brown sun-wrinkled face. Ain't much to look at, he thought, eyeing the sagging folds of skin on his chest and abdomen. My muscles is all turning to flab.

A small, elderly man was sitting in a big swivel armchair, his back to the cluttered roll-top desk that dominated the room. The battered wooden stethoscope extending from his jacket pocket matched his tired face. Shelves along one side were filled with medications, their smells hanging over the room like clouds on a rainy day. The only light came from 2 small windows and the half-opened door. The older man's deep-set eyes seemed focused on some distant unseen horizon. He was deep in thought, beset with too many challenges.

He finally broke the silence. "How much weight you lost, Joseph?" he asked the marshal, his bushy eyebrows obscuring his frowning eyes.

"Doc, I expect it must be around 20 to 30 pounds," the marshal answered. "Leastways, that's what Martha says."

"Must be so, Joseph,” Doc Richards said, "Martha ain't wrong too often."

The doctor made some notes on a pad of paper, the frown on his face fixed, as if painted there a long time ago. Never seen him smile, the marshal thought, and no one ever calls me Joseph except him and Martha.

"How long you had all them twitches in your muscles?" Doc continued.

"That's the funny part," the marshal answered. "I know I'm limping, what with this weak right leg. My arms are getting weak too, but I didn't know I had the twitches until Martha pointed them out. Now that I'm lookin', they're all over my body. What do you think is going on?"

"Joseph, you got a serious muscle disease." Doc Richards compressed his lips and looked directly at him. "I've only seen it a couple of times before. I don't know what causes it and I ain't got any medicine for it."

"What do you think I should do?" the marshal asked. He was afraid to ask the question that really plagued him.

"You're having trouble walking," Doc answered, "and you're slow to get your gun. Never mind you got it hanging around your neck to make it easier to grab. I'm not sure how long you'll be able to shoot straight. Down the road, your breathing may give in. Maybe it's time to quit."

"I ain't gonna get any better?"

Doc slid his chair across the floor until their feet almost touched. Joseph slowly dropped his tired body into the chair behind him, feeling the softness of the gingham shirt against his skin. He felt Doc's hands grasp his.

\section{Correspondence}

Dr. Gutmann

lud-gutmann@uiowa.edu

MORE ONLINE

ค Audio

Listen to Dr. Gutmann read this story.

NPub.org/3xcoq 8 
“Nope, you ain't gettin' better. I'm sorry, it's gonna keep gettin' worse."

Joseph avoided the question he was afraid to ask. He already knew the answer.

"Figure I might end up paralyzed like Pa." It was a statement, not a question. Doc let it go.

"Martha's been saying for months that I need to give it up. Maybe it's time. Even with my gun hanging from my neck, it still takes 2 hands to hold it steady so's I can shoot it. Even then, it's an effort. Never mind I can't get on and off a horse anymore."

As he got up to go, he remembered how hard it was for $\mathrm{Pa}$ to quit after he was paralyzed in that gunfight. All the life seemed to leave him. Being sheriff had been his whole existence. Ma had to take care of him and quit running the dry goods store. It was a terrible time-he was always in pain and depressed.

Joseph would have stopped at the Sheriff's office but he and his deputies were chasing a band of cattle rustlers and wouldn't be back for a few more days. Time enough to tell him he was quitting. He limped across the street to Kenny's Saloon. His slapping right boot kicked up small whirlpools of dust. Wash some of the prairie grit out of my mouth, Joseph thought. And it's awful hot, too. He almost tripped, dragging his right foot up the step.

“There's a rumor goin' around," Kenny, the bartender, said while he poured the marshal's beer, "that Billy Clanton and his brothers are camping outside of town. What with the Sheriff and his boys gone and all that gold stored in the bank vault."

The sheriff and Joseph had talked about the lure of the stored gold but both men had decided that chasing the rustlers was too important. There were no rumors of any outlaws in the area and they decided the gold was safe. They should have known better.

Sweat flowed freely down the marshal's wrinkled face. Billy Clanton. Now that's just what we need. He hadn't thought about the Clantons in years. Pa getting shot happened a long time ago, back when the Clantons were living in town. After the shooting, they moved away. Joseph was still in his teens then and so was Billy - when Old Man Clanton shot Pa in the back and paralyzed him.

The old man was the town ruffian-always in trouble, always drinkin', always in another gunfight. Pa had to arrest him more times than rabbits invading Ma's lettuce patch. Pa finally told Clanton he was no longer welcome in town-after he shot out the window of the saloon for the twentieth time. Clanton shot $\mathrm{Pa}$ in the back while he was walking back to his office. Lying on the street, a bullet in his spine, Pa still got off the shot that killed Old Man Clanton.
Joseph hobbled out to his wagon. Kenny came out to help him up. Nodding to Kenny, he cracked the whip over the horse's head, and slowly rode the mile to his and Martha's farm. His mind was consumed by the Clanton brothers and the memory of the old man.

"You and Doc are right," the marshal said to his wife over biscuits and gravy. "I've got to quit. Says he ain't got no medicine to help me." He paused. "Martha, I'm scared to death. I think I'm gonna die of this muscle problem. It's just gonna keep getting' worse." He felt the tears welling up.

Martha nodded her head. Doc had told her that Joseph had a fatal illness. She had already spent enough tears to fill a wash bucket.

"I ain't no good at my job anymore," Joseph said, "but I got one last chore to do."

Martha nodded. "A chore? It's got to be over that gold stored in the bank. Can't be nothin' else.”

"You're right," he answered. “The Army is sendin' in a squad of soldiers tomorrow but Billy Clanton and his brothers are nearby and that means only one thing."

“I figure it means 2 things. They're going to try stealin' the gold and you're going to try stoppin' 'em," Martha said, standing up. "But with the sheriff and his deputies gone and you all crippled up, you don't have much of a chance.”

Joseph smiled. "Martha, I got a plan. It's gonna get dark soon and I'm goin' back to town now before the moon is out. Maybe you can meet me? I might need a little help.”

Billy and his 5 brothers rode slowly into town. The breeze had died down and the small clouds of dust kicked up by the horses quickly settled back onto the street. A full moon spread a golden glow over the whole town.

Billy gave his brothers strict orders. There was a lot of gold and there would be no foolishness and no drinking. Straight to the bank, blow open the vault room, load the gold into saddle bags, and head out. The only lawman in town was too crippled to stop them. Billy hated gunfights and he figured there wouldn't be any. Gettin' the gold was gonna be like taking a piece of chocolate cake at a church social.

Billy looked around. Nothing moved. Everyone in town knew they were coming. Even the saloon was shut. He and his brothers walked unhurriedly toward the bank. Drawing his Smith and Wesson, Billy blew open the lock with a single shot. The door flew open.

Inside, the bank was dark and quiet. The 6 men stared at the huge thick blocks that dominated the back wall. Stray beams of moonlight reflected off a heavy iron gate, once black but 
now rust-encrusted, embedded in the middle of the stony wall. The vault was an enormous room that extended out behind the bank like a squared-off tail on a beaver. The walls were said to be so thick even a cannonball couldn't penetrate them. The only way in was through the gate.

Billy had carefully planned getting into the vault. One of the brothers attached a small stick of dynamite to the hinged side of the door. Billy signaled for them to back away.

The explosion dislocated the vault door, leaving it hanging half open. Dust filled the entire room. The men lined up in front of the door, 6 across, watching as the dust settled. As the air in the doorway cleared, a shadowy figure began to appear. Like a ghost rising from beneath the floor, seated in an old wooden chair, his back up against the gold bricks and a double-barrel shotgun resting in his lap, was the marshal.

"Good evening, fellas." Billy could see the faint smile flicker across the marshal's face as his eyes fixed on Billy's gun hand. "How 'bout you all just turn around and ride out of town as quietly as you come in." The shotgun was pointed straight at Billy.

"Marshal," Billy began, his drawl low and slow as he and his 5 brothers walked into the vault room, "I got no problem with you. I heard you was all crippled up and dyin' and I got no interest in killin' you, anyway." He paused. "I ain't got nothin' against you. I know your Pap shot my old man but he deserved it. I don't hold with shootin' folks in the back. Besides, Pa was never very nice to us boys. We all got the buckle end of his belt more'n once."

Billy paused. The marshal just sat, both barrels pointed at Billy's midsection.

"Marshal," Billy continued, "There's 6 of us and one of you. There's no sheriff and no posse comin'. Before you get your second shot off, you'll be dead. You can leave right now and there won't be no hard feelin's."
Joseph thought about the weakness of his arms and legs, the twitches, and the cramps. He might not live another year with the illness, but he was sure he was not dying tonight.

"Billy," he said, "I may only get one shot off but that bullet will be in your belly. That's where this gun is pointed and that's where my shot goes. You won't live long enough to hear the Army bugle blowin' in the mornin'."

The conversation stopped. Moonlight drifted into the vault, softly reflecting off the pile of yellow bricks lying along the back wall. A woman's voice broke the quiet.

"In case you think the marshal's here all alone, he ain't." The words came from a dark corner of the bank. "We got more guns back here." No one had seen Martha hiding behind a heavy wooden counter. Joseph was glad they were doing this together.

"You and the boys better get movin', Billy," the marshal said. "The Army'll be here in a couple of hours. I don't suppose they'll take your wanting to steal their gold lightly."

Billy's eyes remained fixed on the shotgun pointed at him. $\mathrm{He}$ was trying to figure how to best deal with this broken-down marshal, his woman, and the devil only knows who else. $\mathrm{He}$ didn't like the idea of killing women, especially the marshal's wife. He signaled his brothers. It was time to leave.

Joseph and Martha didn't move until the hoof beats had receded far into the night. "I think we've seen the worst of the Clantons," he said. "But we'll have to stay here until the Army arrives." He tried to get out of the chair but fell back, the shotgun clanging on the wood floor, the pistol hanging around his neck smashing into his nose. Damn, Joseph thought, this weakness keeps gettin' worse.

The lights in the saloon had flickered on with the last of the hoof beats. The laughter of men drinking began drifting across the street. He reached for Martha's hand. 


\title{
Neurology
}

\author{
The vault \\ Ludwig Gutmann \\ Neurology 2018;91;94-96 \\ DOI 10.1212/WNL.0000000000005760
}

This information is current as of July 9, 2018

\section{Updated Information \& Services}

\section{Subspecialty Collections}

Permissions \& Licensing

\section{Reprints}

including high resolution figures, can be found at: http://n.neurology.org/content/91/2/94.full

This article, along with others on similar topics, appears in the following collection(s):

\section{Amyotrophic lateral sclerosis}

http://n.neurology.org/cgi/collection/amyotrophic_lateral_sclerosis_ Anterior nerve cell disease

http://n.neurology.org/cgi/collection/anterior_nerve_cell_disease

Information about reproducing this article in parts (figures,tables) or in its entirety can be found online at:

http://www.neurology.org/about/about_the_journal\#permissions

Information about ordering reprints can be found online:

http://n.neurology.org/subscribers/advertise

Neurology ${ }^{\circledR}$ is the official journal of the American Academy of Neurology. Published continuously since 1951, it is now a weekly with 48 issues per year. Copyright @ 2018 American Academy of Neurology. All rights reserved. Print ISSN: 0028-3878. Online ISSN: 1526-632X.

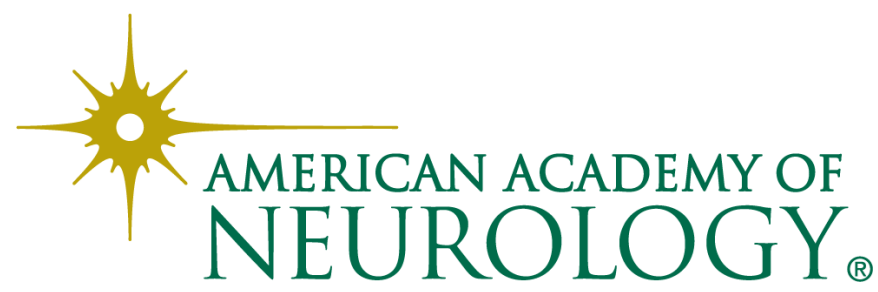

